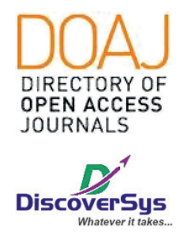

Published by DiscoverSys

\section{Korelasi antara kadar testosteron total dengan trans epidermal water loss (TEWL) pada pria late onset hypogonadism}

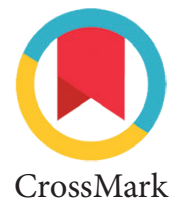

\author{
Daniel Widiyanto, ${ }^{1 *}$ Reny I'tishom ${ }^{2}$
}

\title{
ABSTRACT
}

Background: Late Onset Hypogonadism ( $\mathrm{LOH})$ is a clinical and biochemical condition in the elderly with testosterone levels below the reference value of young and healthy men, accompanied by symptoms of testosterone deficiency. Increased age or aging process is one of the factors causing sebaceous gland function decreased both regarding quantity and regarding quality associated with the function of lipid barrier. Decreased sebum gland function can be seen from several parameters, one of which is the increase of Trans Epidermal Water Loss (TEWL).

Methods: This study was an observational analytic study with cross-sectional design to determine the relationship between total testosterone and TEWL in $\mathrm{LOH}$ men. This research was conducted in Outpatient Unit Andrology of dr. Soetomo from May 2017 to July 2017. 16 samples of elderly male patients ( $\geq 60$ years) were selected using the consecutive sampling technique who met the inclusion and exclusion criteria. Performed total testosterone test and TEWL level examination by using Tewameter to the research sample. Interpretation of results adjusted to Research and Development Department, Courage \& Khazaka Electronics GmbH, Koln, Germany.

Results: The Total testosterone levels of the patient were ranged from 146.11 - $575.10 \mathrm{ng} / \mathrm{dL}$ with a mean of $351.67 \mathrm{ng} / \mathrm{dL}$ and standard deviation of 116.34 . The TEWL level of the patients was ranged from $17.2-50.8 \mathrm{~g} / \mathrm{jam} / \mathrm{m}^{2}$ with a mean of $31 \mathrm{~g} / \mathrm{jam} / \mathrm{m}^{2}$ and standard deviation of 9.20. The correlation coefficient value between total testosterone and TEWL was -0.853 with a significance of $0.0001(\mathrm{p}<0.05)$.

Conclusion: There was a significant relationship between total testosterone and TEWL. The association of total testosterone with TEWL is unidirectional. The lower the testosterone level, the higher the TEWL value.

Keywords: Late Onset Hypogonadism, Trans Epidermal Water Loss

Cite This Article: Widiyanto, D., I'tishom, R. 2018. Korelasi antara kadar testosteron total dengan trans epidermal water loss (TEWL) pada pria late onset hypogonadism. Intisari Sains Medis 9(1): 6-9. D0I: 10.1556/ism.v9i1.144

Latar Belakang: Late Onset Hypogonadism (LOH) adalah kondisi klinik dan biokimiawi pada orang tua dengan kadar testosteron dibawah nilai referensi laki-laki usia muda dan sehat, yang disertai dengan gejala defisiensi testosterone. Bertambahnya usia atau proses penuaan adalah salah satu faktor penyebab fungsi kelenjar sebasea mengalami penurunan baik dari segi kuantitas maupun dari segi kualitas yang berkaitan dengan fungsi lipid barrier. Penurunan fungsi kelenjar sebum dapat dilihat dari beberapa parameter, salah satunya peningkatan Trans Epidermal Water Loss (TEWL).

Metode: Penelitian ini merupakan penelitian analitik observasional dengan desain cross-sectional untuk mengetahui hubungan antara kadar testosteron total dengan TEWL pada pria $\mathrm{LOH}$. Penelitian ini dilakukan diUnit Rawat Jalan Andrologi RSUD dr. Soetomo dari Mei 2017 hingga Juli 2017. Jumlah sampel pasien pria usia lanjut ( $\geq 60$ tahun) sebesar 16 orang yang memenuhi kriteria inklusi dan eksklusi, dipilih menggunakan Teknik konsekutif. Dilakukan pemeriksaan kadar testosteron total dan pemeriksaan kadar TEWL dengan menggunakan Tewameter pada sampel penelitian. Interpretasi hasil disesuaikan dengan Research and Development Department, Courage \& Khazaka Electronics $\mathrm{GmbH}$, Koln, Jerman.

Hasil: Kadar testosteron total pasien berkisar antara 146,11 $575,10 \mathrm{ng} / \mathrm{dL}$ dengan rerata 351,67 ng / dL dan standar deviasi sebesar 116,34. Kadar TEWL pasien berkisar antara 17,2 - 50,8 dengan rerata $31 \mathrm{gram} / \mathrm{jam} /$ meter $^{2}$ dan standar deviasi sebesar 9,20. Nilai koefisien korelasi antara testosteron total dengan TEWL sebesar $-0,853$ dengan signifikansi sebesar $0,0001(p<0,05)$.

Simpulan: Terdapat hubungan yang bermakna antara kadar testosteron total dengan TEWL. Hubungan kadar testosteron total dengan TEWL adalah hubungan tidak searah. Semakin rendah kadar testosteron, semakin tinggi nilai TEWL.
Kedokteran Universitas Airlangga,

Surabaya-Indonesia

Daniel.widiyanto@gmail.com

Diterima: 03-12-2017

Disetujui: 01-01-2018

Diterbitkan: 02-01-2018
Kata kunci: Late Onset Hypogonadism, Trans Epidermal Water Loss

Cite Pasal Ini: Widiyanto, D., I'tishom, R. 2018. Korelasi antara kadar testosteron total dengan trans epidermal water loss (TEWL) pada pria late onset hypogonadism. Intisari Sains Medis 9(1): 6-9. D0I: 10.1556/ism.v9i1.144 


\section{PENDAHULUAN}

Berdasarkan data dari Badan Pusat Statistik (BPS), sejak tahun 2010 - 2015 terdapat peningkatan angka harapan hidup di Indonesia, yaitu 70,1 tahun. Hal ini lebih tinggi dibandingkan pada tahun 2005 - 2010, yaitu 69,1 tahun. ${ }^{1}$ Tingginya angka harapan hidup ini menimbulkan berbagai permasalahan kesehatan terkait dengan proses aging atau penuaan. Salah satu permasalahan yang seringkali timbul adalah gangguan endokrin. ${ }^{2}$ Pada saat pria mengalami penuaan, terjadi penurunan hormon testosteron secara bertahap yang disebut dengan Late Onset Hypogonadism (LOH). LOH adalah kondisi klinik dan biokimiawi yang timbul pada orang tua dengan kadar testosteron di bawah nilai referensi laki-laki usia muda dan sehat, yang disertai dengan gejala defisiensi testosteron. $\mathrm{LOH}$ akan menyebabkan gangguan terhadap kualitas hidup seseorang dan gangguan multiple organ. ${ }^{3}$

Dari beberapa penelitian sebelumnya, didapatkan hubungan antara penurunan progresif kadar terstosteron dengan bertambahnya usia, yaitu terdapat penurunan kadar testosteron sekitar 1-2\% per tahun setelah usia 40 tahun. Pada studi lain ditemukan 20\% laki-laki usia lebih dari 60 tahun kadar testosteron nya lebih rendah. Pada beberapa study ditemukan usia 75 tahun, kadar serum testosteron total sekitar 2/3 dibanding usia 25 tahun, artinya kadar testosteron bebas hanya sekitar $1 / 2$ dari usia muda. Pada penelitian lain ditemukan pada laki-laki sehat usia 61-87 tahun ditemukan penurunan level testosteron rata rata $110 \mathrm{ng} / \mathrm{dL}$ setiap dekade (Julior et al., 2011)

Androgen memiliki peranan penting pada kulit, terutama pada kelenjar sebasea (sebaceous gland). Androgen akan memicu diferensiasi kelenjar sebasea sehingga ukuran dari kelenjar sebasea dan produksi sebum akan meningkat. Jenis androgen yang paling dominan pada kelenjar sebasea adalah testosteron dan dihydrotestosteron (DHT). ${ }^{4}$ Sebum adalah cairan kaya lemak yang dihasilkan oleh sel sel sebosit yang sudah matang. Setelah diproduksi, sebum akan disekresikan ke permukaan kulit. ${ }^{5}$ Sebum sebagai penyusun lipid barrier, berperan penting untuk mempertahankan retensi cairan pada kulit. Kemampuan retensi cairan ini disebabkan karena kandungan asam lemak bebas pada sebum. Bertambahnya usia atau proses penuaan (ageing) adalah salah satu faktor yang menyebabkan mengapa fungsi kelenjar sebasea mengalami penurunan baik dari segi kuantitas maupun dari segi kualitas yang berkaitan dengan fungsi lipid barrier. Pada akhirnya kemampuan mencegah retensi cairan pun juga akan menurun. Penurunan fungsi kelenjar sebum ini dapat dilihat dari beberapa parameter, salah satunya peningkatan
Trans Epidermal Water Loss (TEWL) (Luebberding et al., 2013).

Meskipun sudah ada penelitian mengenai pengaruh umur terhadap TEWL pada pria, namun sampai saat ini belum ada penelitian mengenai TEWL pada pria usia lanjut dengan kadar testosteron total yang rendah. Dengan penelitian ini diharapkan ditemukan korelasi antara kadar testosteron total yang rendah pada pria usia lanjut dengan peningkatan TEWL pada Tewameter.

\section{METODE}

Penelitian ini merupakan penelitian analitik observasional dengan desain cross-sectional. Penelitian ini dilakukan di Unit Rawat Jalan Andrologi RSUD dr. Soetomo dari bulan Mei 2017 hingga Juli 2017. Populasi dalam penelitian ini adalah pasien pria usia lanjut yang berkunjung ke URJ Andrologi RSUD dr. Soetomo Surabaya pada bulan Mei 2017 sampai Juli 2017. 16 orang Sampel dipilih menggunakan Teknik konsekutif, yaitu semua pasien pria usia lanjut yang datang ke URJ Andrologi RSUD dr. Soetomo selama periode Mei 2017 s/d Juli 2017. Sampel dipilih dengan mempertimbangkan kriteria inklusi berupa usia $\geq 60$ tahun dan bersedia diikutkan dalam penelitian dengan menandatangani information of consent dan informed consent. Sedangkan kriteria ekslusi yang digunakan adalah memiliki salah satu atau lebih kondisi (Kelainan kulit seperti dermatitis atopi, psoriasis vulgaris, iktiosis, eksema kronis, Trauma pada kulit seperti luka bakar, Hiperhidrosis, Dehidrasi), sudah dalam terapi hormonal dalam 3 bulan terakhir atau mengkonsumsi obat-obatan serta herbal yang dapat mempengaruhi tingkat testosterone, menggunakan produk topikal yang mempengaruhi kelembaban kulit pada daerah wajah.

Pasien usia lanjut ( $\geq 60$ tahun) ikut masuk sebagai sampel penelitian dijelaskan rencana penelitian yang akan dilakukan dan apabila pasien bersedia untuk ikut dalam penelitian, maka pasien diminta menandatangani information to consent dan informed consent. Dilakukan pemeriksaan kadar testosteron total pada sampel penelitian. Kemudian dilakukan pemeriksaan kadar trans epidermal water loss (TEWL) dengan menggunakan Tewameter. Sebelum diperiksa menggunakan Tewameter, dilakukan anamnesa terlebih dahulu apakah sampel penelitian menggunakan bahan bahan topikal yang akan mempengaruhi TEWL seperti pelembab. Sampel diminta beristirahat sejenak bila berkeringat. Ruang periksa menggunakan ruangan tertutup dengan suhu 23-25 derajat celcius tanpa aliran udara langsung dan tanpa paparan sinar matahari langsung. 
Untuk interpretasi hasil, pembacaan disesuaikan dengan Research and Development Department, Courage \& Khazaka Electronics GmbH, Koln, Jerman yaitu: di bawah $(<) 8 \mathrm{gram} / \mathrm{jam} / \mathrm{meter}^{2}=$ menurun; Antara 8 - 15 gram $/$ jam $/$ meter $^{2}=$ normal; di atas (>) $15 \mathrm{gram} / \mathrm{jam} /$ meter $^{2}=$ meningkat.

Data hasil percobaan kemudian diolah, disajikan dalam bentuk tabel serta dilakukan analisis hasil. Analisis statistik menggunakan program SPSS IBM versi 17.0, SPSS inc., 1989-2007. Uji statistik yang dilakukan meliputi: 1) uji normalitas data menggunakan Kolmogorov Smirnov (KS), 2) data yang berdistribusi normal menggunakan perhitungan korelasi Pearson.

\section{HASIL}

Selama periode penelitian Mei - Juli 2017 didapatkan jumlah sampel pasien pria usia lanjut ( $\geq 60$ tahun) sebesar 16 orang yang memenuhi kriteria inklusi dan eksklusi.

Pasien yang menjadi sampel berusia antara 60 - 75 tahun dengan rerata 66 tahun dan standar deviasi sebesar 4,13. Kadar testosteron total pasien berkisar antara 146,11 - 575,10 ng/dL dengan rerata $351,67 \mathrm{ng} / \mathrm{dL}$ dan standar deviasi sebesar 116,34. Kadar TEWL pasien berkisar antara 17,2 $50,8 \mathrm{~g} / \mathrm{jam} / \mathrm{m}^{2}$ dengan rerata $31 \mathrm{~g} / \mathrm{jam} / \mathrm{m}^{2}$ dan standar deviasi sebesar 9,20 (Tabel 1).

Hasil uji distribusi normal data testosteron total pada sampel menggunakan One Sample Kolmogorov Smirnov Test. Hasil uji menunjukkan bahwa data

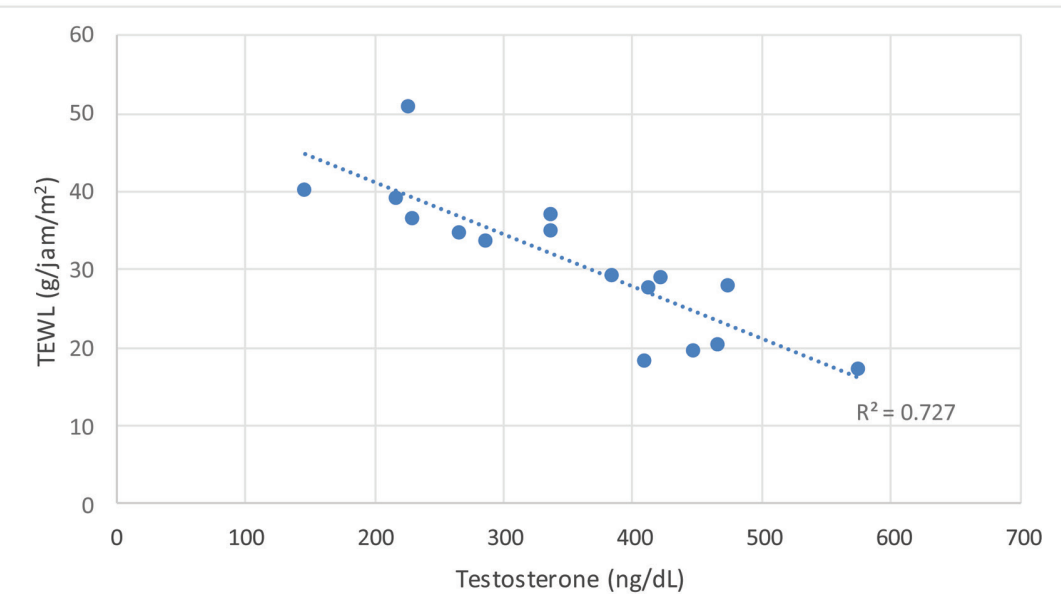

Gambar 1 Korelasi Kadar Testosteron Total dan TEWL

Tabel 1 Karakteristik Sampel Penelitian

\begin{tabular}{lccc}
\hline Variabel & n & Rerata \pm Simpangan Baku & Median (min - maks) \\
\hline Umur (th) & 16 & $66,00 \pm 4,131$ & $65(60-75)$ \\
Testosterone (ng/dL) & 16 & $351,67 \pm 116,338$ & $360,165(146,11-575,10)$ \\
TEWL $\left(\mathrm{g} / \mathrm{jam} / \mathrm{m}^{2}\right)$ & 16 & $31,05 \pm 9,201$ & $31,45(17,2-50,8)$ \\
\hline
\end{tabular}

testosteron total memiliki nilai $\mathrm{p}=0,962$. Hal ini menunjukkan data testosteron total berdistribusi normal $(\mathrm{p}>0,05)$.

Hasil uji distribusi normal data TEWL pada sampel menggunakan One Sample Kolmogorov Smirnov Test. Hasil uji menunjukkan bahwa data TEWL memiliki nilai $\mathrm{p}=0,960$. Hal ini menunjukkan data TEWL berdistribusi normal $(\mathrm{p}>0,05)$.

Karena data testosteron total dan TEWL berdistribusi normal, maka hubungan testosteron total dan TEWL dapat dianalisis menggunakan Uji Korelasi Pearson. Dari hasil uji korelasi Pearson didapatkan nilai koefisien korelasi sebesar $-0,853$ dengan signifikansi sebesar 0,0001 $(\mathrm{p}<0,05)$. Artinya terdapat hubungan yang bermakna antara testosteron total dengan TEWL. Nilai koefisien korelasi negatif menunjukkan hubungan tidak searah, semakin kecil kadar testosteron total maka semakin besar nilai TEWL.

\section{DISKUSI}

Pasien yang menjadi sampel berusia antara 60 75 tahun dengan rerata 66 tahun dan standart deviasi sebesar 4,13. Kadar testosteron total rerata adalah 351,67 ng/dL dengan standart deviasi sebesar 116,34. Hal ini sesuai dengan teori bahwa penurunan kadar testosteron terjadi seiring bertambahnya usia, yaitu terdapat penurunan 1-2\% per tahun setelah usia 40 tahun. (Julior et al., 2011)

Salah satu fungsi sebum yang diukur dalam penelitian ini adalah fungsi barrier lipid. Lipid dari sebum (sebaceous lipids) akan bergabung dengan lipid dari stratum korneum (epidermal lipids) membentuk Skin Surface Lipids (SSL). Asam lemak bebas yang terdapat dalam sebum berfungsi untuk mencegah evaporasi atau hilangnya cairan dari dalam kulit. ${ }^{5}$ Pengukuran dilakukan pada dahi untuk menyingkirkan pengaruh epidermal lipids. Pengukuran TEWL menggunakan alat yang disebut Tewameter. Nilai normal nya adalah $8-15 \mathrm{~g} / \mathrm{jam} / \mathrm{m}^{2}$. Pada penelitian ini rata rata nilai TEWL nya adalah $31,05 \mathrm{~g} / \mathrm{jam} / \mathrm{m}^{2}$ dengan standart deviasi 9,20.

Karena semua data berdistribusi normal, maka dilakukan uji hubungan kadar testosteron total dan TEWL menggunakan Uji Korelasi Pearson. Dari uji yang dilakukan pada semua sampel tersebut, ditemukan koefisiensi korelasi sebesar - 0,853 dengan signfikansi sebesar 0,0001 . Artinya terdapat hubungan yang bermakna antara kadar testosteron total dengan TEWL. Nilai koefisiensi korelasi negatif menunjukkan hubungan tidak searah, artinya semakin rendah testosteron maka semakin tinggi nilai TEWL. Hal ini sesuai dengan hipotesis awal bahwa karena testosteron berperan dalam regulasi fungsi sebum, jika terjadi penurunan kadar 
testosteron maka fungsi sebum akan terganggu termasuk dalam fungsi lipid barrier yang ditunjukkan dengan pemeriksaan TEWL.

\section{KETERBATASAN}

Testosteron yang diperiksa hanya kadar testosteron total tanpa memeriksa kadar SHBG, sehingga tidak dapat melihat kadar testosteron bebas. Dengan testosteron bebas dapat dinilai lebih baik korelasi antara kadar testosteron dan fungsi lipid barrier dari sebum. Adanya faktor faktor lain yang mempengaruhi TEWL yang mungkin tidak diketahui saat penelitian misalnya riwayat penyakit terdahulu yang tidak diketahui sampel sehingga disangkal dalam anamnesa atau status hidrasi. Lingkungan pemeriksaan yang tidak dapat diprediksi, mungkin sedikit banyak akan mempengaruhi hasil pemeriksaan TEWL.

\section{SIMPULAN}

Terdapat hubungan yang bermakna antara kadar testosteron total dengan Trans Epidermal Water Loss (TEWL). Hubungan kadar testosteron total dengan TEWL adalah hubungan tidak searah. Semakin rendah kadar testosteron, semakin tinggi nilai TEWL.

\section{DAFTAR PUSTAKA}

1. Badan Pusat Statistik. Angka Harapan Hidup Penduduk Beberapa Negara (tahun), 1995-2015. 2014. https://www. bps.go.id. Diakses pada 16 Maret 201723.13 pm.

2. Lunenfeld B, Mskhalaya G, Kalinchenko S. Recommendations on The Diagnosis, Treatment and Monitoring of Late Onset Hypogonadism in Men Suggested Update. The Aging Male. 2013. 16(4):143-150.

3. Lunenfeld B, Mskhalaya G, Kalinchenko S. Recommendations on The Diagnosis, Treatment and Monitoring of Late Onset Hypogonadism in Men Suggested Update. The Aging Male. 2013. 16(4):143-150

4. Thiboutot D. Regulation of Human Sebaceous Glands. The Journal of Investigation Dermatology. 2004. 123:1-12.

5. Picardo M, Ottaviani M, Camera E, Mastrofrancesco A. Sebaceous Gland Lipids. Dermato Endocrinology. Mar-Apr 2009. 1(2):68-71.

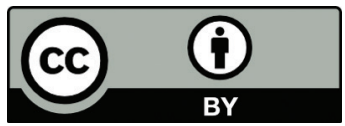

This work is licensed under a Creative Commons Attribution 